\title{
土木”学会論文報告集
}

第 266 .号・1977年 10 月

\section{高異方性弾性体の近似解析理論に関する 二,三の基礎的考察}

\section{SOME BASIC CONSIDERATIONS FOR THE THEORIES OF APPROXIMATE ANALYSIS OF HIGHLY ANISOTROPIC ELASTIC MATERIALS}

\author{
北原 道 弘*.平島健 一**.丹羽義 次*** \\ By Michihiro KITAHARA, Ken-ichi HIRASHIMA and Yoshiji NIWA
}

\section{1. 緒言}

現在, 古典弾性論の再考察が進むにつれて弾性体理論 の枠組の中だけでも, さまざまな方向へ新分野の展開, 開拓がなされている.これらの理論はいずれも連続体の 基本概念のもとに一般論を展開し, その一極限として古 典弾性論を位置づけるものであり, その分枝はここに述 べる “層化された物質”にもその一極限を見ることがで きる. しかしながら，莫大な数にのぼるこれらすべての 理論を総括して理論を進めることは現在のところ不可能 である.たとえ, それが可能としても基礎式は実質的に は解析不可能なものとなるであろう ${ }^{1)}$. 本論文に示す高 異方性弾性体に対する解析方法は古典論の立場を守りな がらも，この範畴で「より特徴的に」注）材料を理想化す ることにより古典異方性弾性体理論のもつ高異方性とし ての極限の問題点を示して再検討を促し，かつ異方性と 不均質性の intersection における 理論の出現を期待す るものである.また，ここで用いる境界層の手法は，あ る意味では古典的手法といえるが, たとえば, 有理連続 体力学 (rational continuum mechanics) ${ }^{15)}$ にいら流体 で満たされた porous な物質などの本質的に非線形物質 を扱う分野においてなんらかの近似解を得ようとする 時, 微小パラメーターの導入は不可避であり, ある意味 では二点境界值問題ともいえるこの一連の概念は有効な 解析手段を与えるものと思われる.ここでは非常に特殊 化された物質から異方性弾性物質を考察するといら立場 を取るが，これは連続体という一般概念から出発する現 在の連続体力学の流れとよい対照をなすものであって, 後者の全体の場を見失わない立場とともに，ここに示す 前者の立場もまた実際的な現象究明という点で有効であ

* 学生会員 工修 京都大学大学院生 博士課程在学

** 正会員 工修 山梨大学助教授 工学部土木工学科

*** 正会員 工博 京都大学教授 工学部土木工学科
ることが指摘でき ると考えるもので ある、いいかえる ならばわれわれ の目的は結晶性物 質の枠組に入り得 ないたとえば， 層化された物質, 繊維強化複合材料

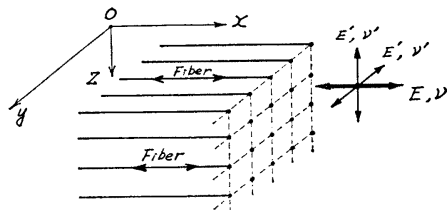

Fig. 1 General View of Orthotropic Elastic Material (Fiber-Reinforced Composite Material) and Coordinate System.

などに古典異方性基礎式を適用するには，乙の構成関係 自身に曖昧性があること, したがって，これに基ゔく基 礎式の複雑性などのために, それをいかに正確に解析し たとしても現実物質の真の挙動推定には必ずしもなりえ ないことを考慮し, より簡単に, より特徽的に高異方性 物質に対し, その異方性比をパラメーターとし, その才 ーダーで応力を推定する手法を試みようとするものであ る.この過程をたどる中で現実物質の持つ二, 三の特質 を見ることができる．ここで強調しておくべきことは， 本論文はあくまで古典異方性弾性体理論の枠組みを出る ものではないが, Fig. 1 に示すような一方向強異方性 弾性物質を解析の対象とする場合，上述した理由によ り，この性質を最も特徵づけるような内部拘束を与え， この拘束の解除という方向から現実物質への接近を計ろ らとするものであり, 古典的意味での異方性弾性論にお ける基礎方程式では表示しえない高異方性物質の持つ一 極限を提示しようとするものである．以下では，簡単に 本論文の基礎となった従来までの研究を概観しておこ 5 .

近年その使用性の増大を呈しつつある繊維補強複合物 質(Fiber Reinforced Composite Materials, 以下 FRC $\mathrm{M}$ と略称する) は,纎維方向の伸びに対する弾性係数が

注）「より特徵的に」とは Fig. 1 に示すような一方向高異 方性弹性体をより強く特徴づけるような「内部拘束」(非伸張あ るいは非圧縮仮定等）を与えること，ぬたはこれに起因するこ と，関連しているという意味を含ませるものとする。 
それに直な方向の值に比較して，しばしば 50 倍あるい はそれ以上の值をとるといら意味において高異方性を呈 する.この種の物質に対する解析手法がさまざまな形で 提案されており，この材料の糼学的取り扱いに対する 理想化の一つの考え方は, 非圧縮, 非伸張と仮定するこ とであり，1971 年 Pipkin \& Rogers ${ }^{2}$ により定式化さ れた.この仮定の特徵は singular fiber (または singular sheet of fibers) と normal-line の出現であり,これら は有限の力, したがって, その結果として無限の忘力を 受け減衰なく長距離にまで力を伝澾することになる。ま

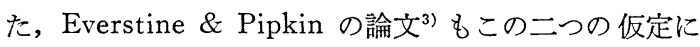
基づいて展開されたものである.すなわち, 彼らは自由 表面付近の高応力集中域の存在とその減衰長および層厚 の尺度を与え, 異方性厳密解の極限としてこの singular fiber の存在が可能であることを証明したものである。

次の力学的モデル化は本論文に示す第 (I) の仮定す なわち，材料を非伸張と仮定することであり，1973 年 England ら゙)によりさまざまな解が提示された.この解 の特性は, Laplace 型の方程式に支配される高異方性弾 性係数の方向 (繊維方向) とは直角な $y$ 方向変位 $v$ の みによる応力 $\sigma_{y y}{ }^{(1)}$ が完全解に対する第一近似となり らるとするものであり,かつまた normal-line 付近の応 力状態に対してよりよい近似となりらるとするものであ る. しかしながら，この理論をもってしてもこの応力特 異 fiber の出現は改善できない.この特異 fiber の出現 を解消すると同時にこの応力不連続性を境界条件として $x$ 方向 (繊維方向) 変位 $u$ について解こうとするのが 第 (II) の仮定 : 境界層 (Boundary Layer) の手法であ る.この特異 fiber 付近の境界層解析は 1973 年 Everstine \& Pipkin $^{5)}$ により片持ばりに対し適用され，Laplace および Poisson 型方程式に対する解法として摂動 法が提示された.この境界層の概念を用いてさらに,1974 年 Spencer ${ }^{6}$ ) は平面ひずみ, 平面応力をも含め, 伸張性, 圧縮性理論へと定式化を広めた.この境界層解は微小パ ラメーターをに支配されることになるが, これは後に 示す一般化重調和方程式の小さい方の特性根 $\varepsilon_{t}$ に相当 する. 本論文では形式化を Spencer に合わせ, 近似理 論 $[I]$ 一非伸張仮定理論——, および近似理論 [II]

境界層存在仮定理論一一よる応力が異方性厳密式 とどのような形で関係するかを検討考察する，なお，理 論的推移は Fourier 変換で統一し, “基礎関数”を導入 して近似理論解ならびに一般化重調和方程式の厳密解と の一致性, それらの対応する項の持つ物理的特性等を示 そうとするものである.

歴史的には, この応力特異層の存在の推定は 1966 年 M.A. Brot ${ }^{7)}$ により, skin effect といら形で議論され, そこでは skin 厚ならびに減衰長は異方性比をパラメー
ターとする $2 つ の$ 特性根に支配されることが示されてお りその基本的概念はここでの非伸張仮定と境界層の存 在仮定による合成応力と同じである.

なお,このような Laplace および Poisson 型方程式 を基礎方程式として FRCM の解析を行うことは合成板 に対しても行われており，その結果は同じように端層に 抢ける高応力集中域の存在を示している ${ }^{8)}$. 次節以下で は, 内部拘束とそれの解除という手順によって現実物質 への接近をめざす理論, すなわち, 近似理論 [I]およ び [II] による二つの Laplace 方程式の 解としての二 つの調和関数 $v, u$ から得られる近似合成応力と, 古典 弾性論における一般化重調和方程式の解としての㛜密解 が半無限平面の問題を例にとって比較される. その結 果, 近似解の精度チェックのための尺度は重調和方程式 の二つの特性根にあることが示される。

\section{2. 平面異方性問題における一般関係式}

Fig. 1 に示すように, $x$ 軸が fiber 方向 ( $y z$-面が 等方性の面) と一致する場合の構成関係は次式で与えら れる.

$$
\left.\begin{array}{l}
e_{x x}=\frac{1}{E} \sigma_{x x}-\frac{\nu}{E} \sigma_{y y}-\frac{\nu}{E} \sigma_{z z} \\
e_{y y}=-\frac{\nu}{E} \sigma_{x x}+\frac{1}{E^{\prime}} \sigma_{y y}-\frac{\nu^{\prime}}{E^{\prime}} \sigma_{z z} \\
e_{z z}=-\frac{\nu}{E} \sigma_{x x}-\frac{\nu^{\prime}}{E^{\prime}} \sigma_{y y}+\frac{1}{E^{\prime}} \sigma_{z z} \\
e_{x y}=\frac{1}{2 \mu_{L}} \sigma_{x y}, e_{z x}=\frac{1}{2 \mu_{L}} \sigma_{z x}, e_{y z}=\frac{1+\nu^{\prime}}{E^{\prime}} \sigma_{y z}
\end{array}\right\}
$$

考察の対象とする二次元平面ひずみ問題に対する一般化 構成関係式と, 後に示すような一般化重調和方程式の係 数 $A, B, C$ との関係は次のようになる.

$$
\begin{aligned}
\sigma_{z z} & =\nu \frac{E^{\prime}}{E} \sigma_{x x}+\nu^{\prime} \sigma_{y y} \\
e_{x x} & =\frac{1}{E}\left(1-\nu^{2} \frac{E^{\prime}}{E}\right) \sigma_{x x}-\frac{\nu}{E}\left(1+\nu^{2}\right) \sigma_{y y} \\
& \equiv A \sigma_{x x}-B \sigma_{y y} \\
e_{y y} & =-\frac{\nu}{E}\left(1+\nu^{2}\right) \sigma_{x x}+\frac{1}{E^{\prime}}\left(1-\nu^{\prime 2}\right) \sigma_{y y} \\
& \equiv-B \sigma_{x x}+C \sigma_{y y}
\end{aligned}
$$

ここで, $D=A C-B^{2}$ と定義すると二次元異方性弹性問 題に括ける基本的関係式は次のように要約される.

a）一般化構成関倸式 :

$$
\left.\begin{array}{l}
\sigma_{x x}=\frac{C}{D} e_{x x}+\frac{B}{D} e_{y y} \equiv L e_{x x}+M e_{y y} \\
\sigma_{y y}=\frac{B}{D} e_{x x}+\frac{A}{D} e_{y y} \equiv M e_{x x}+N e_{y y} \\
\sigma_{x y}=2 \mu_{L} e_{x y}
\end{array}\right\}
$$

b) つり合い方程式 : 


$$
\left.\begin{array}{l}
\sigma_{x x, x}+\sigma_{x y, y}=0 \\
\sigma_{x y, x}+\sigma_{y y, y}=0
\end{array}\right\}
$$

c) 適合条件式

$$
e_{x x, y y}+e_{y y, x x}=2 e_{x y, x y}
$$

d) 基礎方程式（一般化重調和方程式）

$$
A \phi, y y y y+B \phi, x x y y+C \phi, x x x x=0
$$

ここに, コンマの次の指標はその指標の座標での偏微 分を意味するものとする. 構成関係 (1) のもとにつり 合い方程式 (2) を満足する応力関数 $\phi(x, y)$ が適合条 件式（3）をも満足するための条件式として生まれる一 般化重調和方程式（4）を基礎式として 理論を進める, いわゆる応力表示による一般的手法に対し，ここに示す 理想化理論においては変位表示により議論を進め, 高異 方性物質に対する弾性定数間のオーダー評価により構成 関係（1）を「より特徴的に」評価し，この種の高異方 性弾性物質の持つ一極限的特質を明らかにする.

\section{3. 非圧縮, 非伸張仮定の理論}

Pipkin ら ${ }^{2)} に よ り$ 導入された 概念は次のようなもの である。

(a) 非伸張仮定 :

$$
e_{x x}=u, x=0 \quad \therefore u=u(y)
$$

(b) 非圧縮仮定 :

$$
u, x+v, y=0 \quad \therefore v=v(x)
$$

(c) 構成関係式:

$$
\left.\begin{array}{rl}
\sigma_{x x} & =T_{1} \\
\sigma_{y y} & =T_{2} \\
\sigma_{x y} & =\mu_{L}[u(y), y+v(x), x]
\end{array}\right)
$$

ここに， $T_{1}$ および $T_{2}$ は不定応力である.

つり合い方程式 (2) を積分すると次式がえられる.

$$
\left.\begin{array}{l}
\sigma_{x x}=-\int_{0}^{x} \sigma_{x y, y} d x=-\mu_{L} x \cdot u(y)_{, y y}+F_{1}(y) \\
\sigma_{y y}=-\int_{0}^{y} \sigma_{x y, x} d y=-\mu_{L} \cdot y \cdot v(x)_{, x x}+F_{2}(x)
\end{array}\right\}
$$

無限遠点では無态力であるといら境界条件を考えること により,

$$
\left.\begin{array}{l}
u(y), y y=0 \\
v(x), x x=0
\end{array}\right\}
$$

これから, $u(y)=\alpha_{1} y+\alpha_{2}, v(x)=\alpha_{3} x+\alpha_{4}$ なる解が可 能であるが, これは無限遠で一定せん断力を受ける場合 だけしか考えられず, したがって, 無限遠での境界条件 としてこれを設けないかぎり $u(y), v(x)$ からの垂直 応力 $\sigma_{x x}, \sigma_{y y}$ への寄与はない. 2 つの積分定数 $F_{1}(y)$, $F_{2}(x)$ は物理的には作用外力を剛 fiber のみが負担す るものとして解釈できる.ここでの二つの仮定が以下に 示す近似理論の基礎となるものである. すなわち, 近似
理論 [I］においては非圧縮仮定（6）をはずすもので あり, 近似理論 [II] においては fiber 方向の非伸張仮 定 (5)をはずすと同時に, 近似理論 [I］により生じた 境界近傍での難点を解消するものである.

\section{4. 近似理論 $[\mathbf{I}]$ 一非伸張仮定理論(4)-}

(a) fiber 方向の非伸張仮定 :

$$
u, x=0 \quad \therefore u=u(y)
$$

(b) 構成関係式:

$$
\left.\begin{array}{l}
\sigma_{x x}=\bar{T} \\
\sigma_{y y}=N e_{y y}=N v(x, y), y \\
\sigma_{x y}=\mu_{L}[u(y), y+v(x, y), x]
\end{array}\right\}
$$

$$
\text { ここに, } \quad N= \begin{cases}\lambda+2 \mu_{T}:(\text { 圧縮性, 平面ひずみ状態) } \\ 4 \mu_{T}\left(\lambda+\mu_{T}\right) /\left(\lambda+2 \mu_{T}\right): \\ \quad: \text { (圧縮性, 平面応力状態) } \\ \infty \quad: \text { (非圧縮性, 平面ひずみ状態) } \\ 4 \mu_{T} \quad: \text { (非圧縮性, 平面応力状態) }\end{cases}
$$

(11), (2) より変位表示のつり合い方程式は次の式とな る.

$$
\left.\begin{array}{l}
\bar{T}, x+\mu_{L}\left[u(y), y_{y}+v(x, y), x y\right]=0 \\
\mu_{L} v(x, y){ }_{x x}+N v(x, y), y y=0
\end{array}\right\}
$$

(12) の第一式を積分することにより不定応力 $\sigma_{x x}$ が次 のように決定できる.

$$
\bar{T}=\sigma_{x x}=-\mu_{L}[x u(y), y y+v(x, y), y]+F_{1}(y)
$$

これより次節に述べる境界層において, $x$ 方向変位 $u$ は「より特徵的に」評価される. 他方, $x$ 方向の非伸張 仮定による応力は (9) から $y$ 方向変位 $v$ のみにより 次のように評価される.

仮定 (I) : 非伸張仮定における構成関係式の仮定

$$
\left.\begin{array}{l}
\sigma_{x x}=-\mu_{L} v, y+F(y) \\
\sigma_{y y}=N v, y \\
\sigma_{x y}=\mu_{L} v, x
\end{array}\right\}
$$

また，(12）の第二式で $c^{2}=\mu_{L} / N, y_{1}=c y$ とおけば, つり合い方程式は次式で表示される.

$$
v, x x+v, y_{1} y_{1}=0
$$

ゆえに, 変位 $v$ は $x$ と $y_{1}$ に関する調和関数となる.

\section{5. 近似理論 $[\mathrm{II}]$ 一境界層の存在の仮定 ${ }^{5,, 6)}-$}

後に示す解析例でわかるようにこの仮定における解の 境界依存性と卓越性を考慮して, 変位成分 $u$ によ支配 される応力場を境界層注）と名付けて，この層内における

注）流体力学で用いられる「境界層」のイメージと同等であ る.ここでは非伸張場が完全流体部分に，境界層場が粘性の卓 越するいわゆる 境界層に対応していると考えてよい。 ある物理 量の境界近傍の卓越性は流体に限らずしばしば 観察される現象 であるが,ここでは「変位による応力の境界近傍依存性と卓越性」 に基ゔいて境界層と呼ぶことにする。 
材料特性に基づく近似法を述べる．（1)，(2) より変位表 示したつり合い方程式は次式で示される.

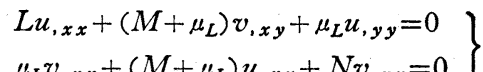

ここに,

$$
\varepsilon^{2}=\mu_{L} / L, c^{2}=\mu_{L} / N, d^{2}=\mu_{L} / M .
$$

たとえば,Spencer ${ }^{6)}$ は FRCM の実在材料に対し異方 性弹性定数を実測した Markham の結果 ${ }^{10)}$ の一例を用 いて上記の $3 つ の$ 材料特性 パラメーターが $\varepsilon^{2}=0.023$, $c^{2}=0.540, d^{2}=1.123$ となることを示している. したが って, 非伸張仮定により生じる境界特異 fiber 近傍の尺

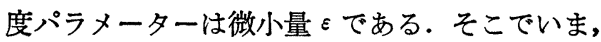

$$
\eta=y / \varepsilon \cdots
$$

により境界層変数 クを導入すると,つり合い方程式 (15) は $\varepsilon, c$ および $d$ を用いて次のように表示できる.

$$
\left.\begin{array}{l}
u_{, x x}+\varepsilon\left(1 / d^{2}+1\right) v_{, x \eta}+u_{, \eta \eta}=0 \\
\varepsilon^{2} v_{x x}+\varepsilon\left(1 / d^{2}+1\right) u_{, x \eta}+\frac{1}{c^{2}} v_{, \eta \eta}=0
\end{array}\right\}
$$

ここで対象としている材料特性 $\varepsilon \ll 1.0, c<1.0, d \fallingdotseq 1.0$ を考虑すると境界層内における卓越変位成分は $u$ であ ることがわかる．沛えに境界層内で vからの寄与はた かだか $\max \left\{O(\varepsilon), O\left(\varepsilon^{2} / c^{2}\right)\right\} ，(\varepsilon \ll 1)$ の程度であること をふまえ, これを無視する. この場合, 境界層内での非 卓越応力 $\sigma_{y y}$ は $y$ 方向のつり合い方程式から次のよう に求まる.

$$
\sigma_{y y}=-\int_{0}^{y} \sigma_{y x}, x d y=-\mu_{L} u_{, x}
$$

ゆえに, 境界層内での構成関係法差 $\max \left\{O(\varepsilon), O\left(\varepsilon^{2} /\right.\right.$ $\left.\left.c^{2}\right)\right\}$ のもとに次のように表現できる.

仮定（II）：境界層における構成関倸式の仮定

$$
\left.\begin{array}{l}
\sigma_{x x}=\frac{\mu_{L}}{\varepsilon^{2}} u_{, x} \\
\sigma_{y y}=-\mu_{L} u_{, x} \\
\sigma_{x y}=\frac{\mu_{L}}{\varepsilon^{2}} u_{, \eta}
\end{array}\right\}
$$

同じ近似度のもとにつり合い方程式は次式により表現で きる.

$$
u, x x+u,{ }_{\eta \eta}=0
$$

ゆえに，変位 $u$ は $x$ と $\eta$ に関する調和関数となる.

ここで，仮定 (I) および (II) を通じ，変位 $v お$ よび $u$ はそれぞれ $\left(x, y_{1}\right)$ および $(x, \eta)$ の調和関数 となったが, この各変数に対する導関数も調和関数であ るという性質は，応力算出において有効に用いられる.

\section{6. 近似理論 $[I]$ および $[I I]$ による态力場とそ れらの解の合成}

次節に示すように fiber 方向に非伸張と仮定した場合
（仮定 (I ））の応力場は, 境界で応力に不連続特異性を 示す.この特異性を境界層の存在仮定 (II) に上り境界 条件として導入することにすれば，この不連続特異性は 解消されることになる. このことは仮定 (I) および （II）の合成として応力場を近似するための一手法を与 えうることを示唆している.ここで仮定と近似法ならび に基礎式を再確認しておく.

仮定 (I)：近似理論 [I］による構成関係およびっ り合い方程式は $y$ 方向（fiber に垂直な方向）の変位 $v$ のみによりそれぞれ式（13）および（14）のように表示 できる.

仮定 (II)：近似理論［II]による構成関倸およびっ り合い方程式は $x$ 方向 (fiber 方向) の変位 $u$ のみに よりそれぞれ式(18)および（19）のように表示できる.

仮定 (III)：考察の対象としている高異方性物質の応 力場は, 近似的に上記 2 つの応力場の重ね合わせとして 次のように表示できる。

$$
\begin{aligned}
& \left.\begin{array}{l}
\sigma_{x x}=\sigma_{x x}{ }^{(I)}+\sigma_{x x}(\text { II }) \\
\sigma_{y y}=\sigma_{y y}(\text { I })+\sigma_{y y}(\text { II }) \\
\sigma_{x y}=\sigma_{x y}(\text { I })+\sigma_{x y}(\text { II })
\end{array}\right\} \\
& \text { ここに, } \\
& \left\{\sigma_{x x^{(1)}}, \sigma_{y y}{ }^{(1)}, \sigma_{x y}{ }^{(1)}\right\}: \\
& \text { 非伸張仮定 (I) に上る応力 [式 (13)] } \\
& \left\{\sigma_{x x}{ }^{(\mathrm{II})}, \sigma_{y y}{ }^{(\mathrm{II})}, \sigma_{x y}{ }^{(\mathrm{II})}\right\} \text { : }
\end{aligned}
$$$$
\text { 境界層仮定（II）による応力 [式 (18)］ }
$$

通常の弾性問題に扔ける変位 (応力) 場は重調和方程 式を満足するが, この仮定のもとでは変位（応力）場は 二つの調和関数で近似されることになり, 弾性問題は二 つの Laplace 型の方程式を境界条件のもとに順次解く ことに帰着する.

ここで近似手法に扔ける境界条件の与え方について説 明しておこう。まず，この近似手法によれば，問題とす る異方性場は非伸張場と境界層場の和として表示しうる ことを注意する．そして，与えられた境界条件は非伸張 場を解くために用いられる.したがって, 問題となる点 は境界層場を解析する際の境界条件の与え方である.こ れを次のように考える. 今まで非伸張仮定の変位 $v(x$, $\left.y_{1}\right)$ および境界層仮定の変位 $u(x, \eta)$ は，それぞれ仮 定（I）および（II）に基づき，全体の異方性変位場 $\{u(x, y), v(x, y)\}$ に対し, 独立に卓越成分をある材 質的な近似度のもとに取り出したものであった。しか し,この 2 つの近似変位場 $\left\{u(x, \eta), v\left(x, y_{1}\right)\right\}$ は本来 独立なものではなく, 全体の変位場 $\{u(x, y), v(x, y)\}$ が応力との関係において一般化 Hooke 法則で結ばれる ように，近似理論 [I］および［II］においてもその合 成として何らかの関係を満足するものでなくてはならな い.ここでは，全体の高異方性変位場を非伸張場に拘束 
し，かつこれを境界層場の導入により開放するという理 論構成のもとに境界層境界せん断応力が, 非伸張境界せ 几断応力からなめらかに導入されるように二つの応力場 を合成する.すなわち, 次の近似合成解において具体的 に示されるように非伸張仮定解において本質的に生じる 境界特異 fiber に対して，一般化構成関係式 (1) を通 じて境界層に対する境界条件とする。

以下, 近似解, 厳密解を通じて使用する基礎関数を次 のように定義しておく.

$$
\left.\begin{array}{rl}
G_{c}(x, y) & =\frac{1}{2 \pi} \int_{-\infty}^{\infty} e^{-i \xi x} \cdot e^{-|\xi| y} d \xi \\
& =\frac{1}{2 \pi} \int_{-\infty}^{\infty} \cos \xi x \cdot e^{-|\xi| y} d \xi=\frac{1}{\pi} \cdot \frac{y}{x^{2}+y^{2}} \\
G_{s}(x, y) & =\frac{1}{2 \pi} \int_{-\infty}^{\infty} \frac{i \xi}{|\xi|} e^{-i \xi x} \cdot e^{-|\xi| y} d \xi \\
& =\frac{1}{2 \pi} \int_{-\infty}^{\infty} \sin \xi x \cdot e^{-|\xi| y} d \xi=\frac{1}{\pi} \cdot \frac{x}{x^{2}+y^{2}}
\end{array}\right\}
$$

以下の議論において $y$ は次のように置き換えて使用され る.

近似理論 [I ] : $y \rightarrow y_{1}=c y$

近似理論 $[$ II $]: y \rightarrow \eta=y / \varepsilon$

これに対応する厳密解の各項においては

$$
\begin{aligned}
& y \rightarrow \bar{y}_{1}=\varepsilon_{c} y \\
& y \rightarrow \bar{\eta}=y / \varepsilon_{t}
\end{aligned}
$$

となる.ここに, $\varepsilon, c$ は 4., 5. において定義されたもの であり, $\varepsilon_{t}, \varepsilon_{c}$ は 8. に述べる一般化重調和方程式の特 性根（またはその逆数）である.また，基礎関数 $G_{c}(x$, $y)$ および $G_{s}(x, y)$ と任意関数 $\varphi(x)$ との合成積は $y$ をパラメーターと見なして， $x$ 変数について合成積をと るという意味で次のように記す。

$$
\begin{aligned}
G_{c}(x, y) * \varphi(x) & =\int_{-\infty}^{\infty} G_{c}(x-t, y) \cdot \varphi(t) d t \\
& =\int_{-\infty}^{\infty} G_{c}(t, y) \cdot \varphi(x-t) d t
\end{aligned}
$$

厳密解と近似解のオーダー評価においては通常の記述方 式 (Landau の記号) に従うものとする. すなわち, 連 続関数 $f, g$ に対し,

$$
\begin{aligned}
f=O(g) \rightleftarrows \boldsymbol{g} c,\|f\| \leq c\|g\| ; \\
\\
f=O(g) \rightleftarrows \boldsymbol{V} \varepsilon,\|f\| \leq \varepsilon\|g\|
\end{aligned}
$$

を意味するものとする.さらにまた，片側 Fourier 変換 および逆変換を次のように定義しておく ${ }^{11)}$.

$$
\left.\begin{array}{rl}
F[u(x, y) ; x \rightarrow \xi] & \\
=\hat{u}(\xi, y) & =\int_{-\infty}^{\infty} e^{-i x \xi} u(x, y) d x, \\
F^{-1}[\hat{u}(\xi, y) ; \xi & \rightarrow x] \\
=u(x, y) & =\frac{1}{2 \pi} \int_{-\infty}^{\infty} e^{i x \xi} \hat{u}(\xi, y) d \xi,
\end{array}\right\}
$$

\section{7. 近似合成解}

平面ひずみ問題を例にとり半無限体の表面に Fig. 2 に示すような，(A) fiber に垂直な分布荷重 $p(x)$ のみ が作用する場合，および

(B) fiber に平行な分布 荷重 $s(x)$ のみが作用す る場合の二種類の境界条 件を考え，非伸張仮定 (I) 加境界層仮定 (II) へと順次, 基礎 (Laplace) 方程式を Fourier 変換により追跡し, 理想 化された解の特性を考察 する.

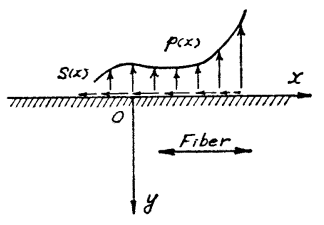

Fig.2 Half Plane Subjected to Arbitrary Normal Stress $p(x)$ and Tangential Stress $s(x)$ at the Surface Boundary.

（A） fiber に垂直な分布荷重 $p(x)$ のみが作用する 場合

a） 近似理論 [I]一非伸張仮定解一

\section{基礎方程式}

$$
v, x x+v, y_{1} y_{1}=0
$$

境界条件式

$$
\frac{\mu_{L}}{c} v\left(x, y_{1}\right), y_{1}=p(x),\left(y_{1}=0 \text { において }\right)
$$

$x$ 成分に対し Fourier 変換を行うと基䃈式および境界 条件は次の上うになる。

$$
\left.\begin{array}{l}
\hat{v}\left(\xi, y_{1}\right), y_{1} y_{1}-\xi^{2} \hat{v}\left(\xi, y_{1}\right)=0, \\
\lim _{y_{1} \rightarrow 0} \frac{\mu_{L}}{c} \hat{v}\left(\xi, y_{1}\right), y_{1}=\hat{p}(\xi), \\
\lim _{y_{1} \rightarrow \infty} \hat{v}\left(\xi, y_{1}\right)=0,
\end{array}\right\}
$$

これより $\hat{v}\left(\xi, y_{1}\right)$ が求まり，逆変換 $v\left(x, y_{1}\right)$ が, さ らに微分により $v, x, v, y$ が次のように定められる.

$$
\begin{aligned}
\hat{v}\left(\xi, y_{1}\right) & =-\frac{c}{\mu_{L}} \frac{\hat{p}(\xi)}{|\xi|} e^{-|\xi| y_{1},} \\
v\left(x, y_{1}\right) & =\frac{1}{2 \pi} \int_{-\infty}^{\infty} e^{i \xi x} \cdot \hat{v}\left(\xi, y_{1}\right) d \xi \\
& =\frac{1}{2 \pi} \frac{c}{\mu_{L}} \int_{-\infty}^{\infty} \log \left(t^{2}+y_{1}{ }^{2}\right) \cdot p(x-t) d t, \\
v\left(x, y_{1}\right), y_{1} & =\frac{c}{\mu_{L}} \int_{-\infty}^{\infty} G_{c}\left(t, y_{1}\right) \cdot p(x-t) d t \\
& \equiv \frac{c}{\mu_{L}} G_{c}\left(x, y_{1}\right) * p(x), \\
v\left(x, y_{1}\right), x & =\frac{c}{\mu_{L}} G_{s}\left(x, y_{1}\right) * p(x) .
\end{aligned}
$$

これより非伸張仮定の場合に対する応力一般式が (13) を用いて次のように求められる.

$$
\begin{aligned}
\sigma_{x x}(\mathrm{I}) & =-c \mu_{L} v, y_{1}+F(y) \\
& =-c^{2} G_{c}\left(x, y_{1}\right) * p(x),
\end{aligned}
$$




$$
\left.\begin{array}{l}
\sigma_{y y}{ }^{(\mathrm{I})}=\frac{\mu_{L}}{c} v_{, y_{1}}=G_{c}\left(x, y_{1}\right) * p(x) \\
\sigma_{x y}{ }^{(\mathrm{I})}=\mu_{L} v, x=c G_{s}\left(x, y_{1}\right) * p(x) \cdot H\left(y_{+0}\right)
\end{array}\right\}
$$

ここに, $H\left(y_{+0}\right)$ : Heaviside の ステップ関数, $G_{c}(x$, $\left.y_{1}\right)$ および $G_{s}\left(x, y_{1}\right)$ は基礎関数の定義式 (21) で $y_{1}$ =cy と置いたものである.

さて，ここで境界条件の検討を行っておこう.

$$
\begin{aligned}
\lim _{y_{1} \rightarrow 0} \sigma_{x x}{ }^{(I)}\left(x, y_{1}\right) & =-c^{2} p(x), \\
\lim _{y_{1} \rightarrow 0} \sigma_{y y}{ }^{(I)}\left(x, y_{1}\right) & =p(x), \\
\lim _{y_{1} \rightarrow 0} \sigma_{x y}{ }^{(I)}\left(x, y_{1}\right) & =\mu_{L} \frac{\partial v(x, 0)}{\partial x} \\
& =\frac{c}{\pi} \cdot \int_{-\infty}^{\infty} \frac{p(t)}{x-t} d t
\end{aligned}
$$

となって, 境界条件 $\lim _{y_{1} \rightarrow 0} \sigma_{x y}{ }^{(\mathrm{I})}\left(x, y_{1}\right)=0$ が満足されて いないことがわかる. 非伸張仮定理論の枠内でこのせん 断応力の不連続性を解消しようとする場合（すなわち， $\sigma_{x y}{ }^{(\mathrm{I})}(x, 0)=0$ を実現しようとする場合), 境界 fiber に次のような合応力が作用すると考えてのみ正当化しう る.

$$
\begin{aligned}
T(x) & =-\mu_{L} \int_{0}^{x} \frac{\partial v(x, 0)}{\partial x} d x+T(0) \\
& =-\mu_{L}[v(x, 0)-v(0,0)]+T(0)
\end{aligned}
$$

$T(x)$ の不定性を考慮して, $T(0)=-\mu_{L} v(0,0)$ とおく と, せん断応力に対する境界条件を満足させるために， 境界上の fiber 方向応力 $\sigma_{x x}(x, 0)$ への寄与 (換算) は 次のように求められる.

$$
\begin{array}{r}
T(x)=-\mu_{L} v(x, 0)=-\frac{c}{\pi} \int_{-\infty}^{\infty} \log |t| \cdot p(x-t) d t \\
(y=0 \text { において })
\end{array}
$$

これは Laplace 方程式の解として, $v$ が対数特異性を 有することに起因するものであり, 非伸張仮定のもとで は, 境界上のせん断応力の不連続性を打ち消す形で fiber 方向応力 $\sigma_{x x}$ に対数的特異性が出現することにな る. 6. における境界条件の与え方 (16 頁参照) におい て説明したように，この状況の出現が境界層概念導入の 動機となるものであり，ここに生じた非現実性を除去す るものが次節で述べる境界層理論である.すなわち, 非 伸張仮定により生じたせん断応力の不連続性を新しい変 位場 $u(x, y)$ に対する境界条件として 導入することに より,このせん断応力不連続性とその結果生じた $\sigma_{x x}$ の 対数的特異性を同時に解消しようとするものである.

なお, 非伸張応力のオーダー評価は,

$$
\sigma_{x x}(\mathrm{I})=O\left(c^{3}\right), \sigma_{y y}(\mathrm{I})=O(c), \sigma_{x y}(\mathrm{I})=O(c)
$$

であり, $c \ll 1$ の場合 $\sigma_{x x}$ (I) の影響は特異 fiber を除く と非常に小さいものであることがわかる.

ここで近似理論 $[I]$ および $[I I]$ の設定の動機とな った非圧縮, 非伸張理論 と 基礎関数 $G_{c}\left(x, y_{1}\right)$ の物理
的意味について述べておく.ここで導入された非伸張 基礎関数 $G_{c}\left(x, y_{1}\right)=\frac{1}{\pi} \cdot \frac{c y}{x^{2}+c^{2} y^{2}}$ は非圧縮性の場合 において物質定数の極限を考えると $c \rightarrow 0(N \rightarrow \infty)$ と なることから, $\lim _{c \rightarrow 0} G_{c}\left(x, y_{1}\right)=\delta(x)$ すなわち, 物質極 限としてデルタ関数の性格を持ち, このとき, 非圧縮, 非伸張仮定の応力 $\sigma_{y y}{ }^{(I)}$ は

$$
\begin{aligned}
\lim _{c \rightarrow 0} \sigma_{y y}(\mathrm{I}) & =\lim _{c \rightarrow 0} G_{c}\left(x, y_{1}\right) * p(x) \\
& =\int_{-\infty}^{\infty} \delta(t) p(x-t) d t=p(x)
\end{aligned}
$$

となり他方, 非圧縮, 非伸張極限のもとでは $\sigma_{y y}$ は $y$ に無関係に $y \rightarrow \infty$ にまで減衰なく伝達されることにな る. また, 非伸張仮定の応力式 (26) において境界 fiber $(y=0)$ にせん断応力 $\sigma_{x y}(\mathrm{I})$ の不連続を生じ, その結果 として $\sigma_{x x}{ }^{(\mathrm{I})}$ に特異項が出現したが, この応力特異性 は $y$ 方向変位 $v$ に対する Laplace 方程式のみでは解 消できない. 以下に述べる境界層解においてこの不連続 性を構成関係を通じて境界条件として導入し, せん断応 力の不連続性ならびに $\sigma_{x x}(\mathrm{I})$ の特異性を解消する.

b) 近似理論 [II]一境界層解一

6. ならびに上記の 非伸張仮定解の項で述べたように 境界層に対する境界条件は $p(x)$ のみ作用する場合に 対しては非伸張変位ひから次の条件により導入される.

$$
\sigma_{x y}{ }^{(\mathrm{II})}=\frac{\mu_{L}}{\varepsilon} u_{, \eta}+\mu_{L} v, x=0 \quad(\eta=0 \text { において })
$$

これより境界層仮定理論に対する基礎方程式および境界 条件式はそれぞれ次のようになる.

$$
\begin{aligned}
& u_{, x x}+u_{, \eta \eta}=0 \\
& u, \eta=-\varepsilon v, x \quad(\eta=0 \text { で }) \\
& \left.u_{, \eta}=0 \quad(\eta \rightarrow \infty \text { で })\right\}
\end{aligned}
$$

a) と同様な $x$ 変数に対する Fourier 変換手法によ り，境界層における応力は（18）より次のように表わさ れる。

$$
\begin{aligned}
& \sigma_{x x}(\mathrm{II})=\frac{\mu_{L}}{\varepsilon^{2}} u, x=\frac{c}{\varepsilon} G_{c}(x, \eta) * p(x) \\
& \sigma_{y y}{ }^{(\mathrm{II})}=-\mu_{L} u_{, x}=-\varepsilon c G_{c}(x, \eta) * p(x) \\
& \sigma_{x y}{ }^{(\mathrm{II})}=\frac{\mu_{L}}{\varepsilon} u_{, \eta}=-c G_{s}(x, \eta) * p(x)
\end{aligned}
$$

ここで, 境界層応力のオーダー評価を行うと

$$
\sigma_{x x}{ }^{(\mathrm{II})}=O\left(c / \varepsilon^{2}\right), \sigma_{y y}{ }^{(\mathrm{II})}=O(c), \sigma_{x y}{ }^{(\mathrm{II})}=O(c)
$$

となり, $\varepsilon \ll 1$ より非伸張応力の場合とは逆に $\sigma_{x x}($ II) $の$ 影響がきわめて大きいことがわかる．これは，非伸張仮 定解における特異境界の解消による境界近傍での境界層 解の特性を強く物語るものである.

(B) fiber に平行な 分布荷重 $s(x)$ のみが作用する 場合

a) 近似理論 [I]

fiber 方向の非伸張性の仮定により, fiber に平行な外 力が作用する場合は, 非伸張変位 $v$ は誘発され得ない. 
ゆえに，非伸張仮定の応力は次のようになる.

$$
\begin{aligned}
\sigma_{x x}(\mathrm{I}) & =-\mu_{L} v_{, y}+F(y) \\
& =\int_{-\infty}^{\infty} s(x) \cdot \operatorname{sgn}(x) \cdot \delta(y) d x \\
\sigma_{y y}(\mathrm{I}) & =0 \\
\sigma_{x y}(\mathrm{I}) & =0
\end{aligned}
$$

b) 近似理論 [II]

境界層解に対する境界条件は次の式により示される.

$$
\sigma_{x \dot{y}}(\mathbb{I})=\frac{\mu_{L}}{\varepsilon} u_{, \eta}+\mu_{L} v, x=s(x) \quad(\eta=0 \text { において })
$$

いまの場合, $v=0$ より基礎方程式ならびに境界条件は 次のようになる.

$$
\begin{aligned}
& u_{, x x}+u_{, \eta \eta}=0 \\
& u_{, \eta}=\frac{\varepsilon}{\mu_{L}} s(x) \quad(\eta=0 \\
& u, \eta=0 \quad(\eta \rightarrow \infty \text { で })
\end{aligned}
$$

前と同じ手法により, $s(x)$ が作用する場合の境界層応 力は (18) より次のように求められる.

$$
\begin{aligned}
& \sigma_{x x}(\mathrm{I})=\frac{\mu_{L}}{\varepsilon^{2}} u_{, x}=\frac{1}{\varepsilon} G_{s}(x, \eta) * s(x) \\
& \sigma_{y y}(\mathbb{I})=-\mu_{L} u_{, x}=-\varepsilon G_{s}(x, \eta) * s(x) \\
& \sigma_{x y}(\mathrm{II})=\frac{\mu_{L}}{\varepsilon} u_{, \eta}=G_{c}(x, \eta) * s(x)
\end{aligned}
$$

オーダー評価を行らと,

$$
\sigma_{x x}(\mathbb{I})=O(1 / \varepsilon), \sigma_{y y}{ }^{(\mathbb{I})}=O(\varepsilon), \sigma_{x y}{ }^{(\mathbb{I})}=O(1 / \varepsilon)
$$

ここでも, $\varepsilon \ll 1$ より $\sigma_{y y}{ }^{(\mathbb{I})} \ll 1$ となり境界層の性格が 現われている.

ここで, 近似理論における一般解として合成応力を示 すと以下のようになる.

$$
\text { (A) } \begin{aligned}
p(x) & \text { が作用する場合 } \\
\sigma_{x x}= & \sigma_{x x}(\mathrm{I})+\sigma_{x x}(\mathrm{I})=-c^{2} G_{c}\left(x, y_{1}\right) * p(x) \\
& +\frac{c}{\varepsilon} G_{c}(x, \eta) * p(x), \\
\sigma_{y y}= & \sigma_{y y}(\mathrm{I})+\sigma_{y y}(\mathbb{I})=G_{c}\left(x, y_{1}\right) * p(x) \\
& -\varepsilon c G_{c}(x, \eta) * p(x), \\
\sigma_{x y}= & \sigma_{x y}(\mathrm{I})+\sigma_{x y}{ }^{(\mathbb{I})}=c G_{s}\left(x, y_{1}\right) * p(x) \\
& -c G_{s}(x, \eta) * p(x) .
\end{aligned}
$$

(B) $s(x)$ が作用する場合

$$
\left.\begin{array}{l}
\sigma_{x x}=\sigma_{x x}(\mathrm{I})+\sigma_{x x}(\mathrm{I})=0+\frac{1}{\varepsilon} G_{s}(x, \eta) * s(x), \\
\sigma_{y y}=\sigma_{y y}(\mathrm{I})+\sigma_{y y}(\mathrm{I})=0-\varepsilon G_{s}(x, \eta) * s(x) \\
\sigma_{x y}=\sigma_{x y}(\mathrm{I})+\sigma_{x y}(\mathbb{I})=0+G_{c}(x, \eta) * s(x)
\end{array}\right\}
$$

後に示すように弾性厳密解を二つの特性根 $\varepsilon_{t}, \varepsilon_{c}$ を用い て示すことによって, ここで求めた近似合成解は $\varepsilon_{t} \rightarrow$ $\varepsilon, \varepsilon_{c} \rightarrow c$ と置き換えることにより $p(x)$ の作用下にお いては, 後出の俰数 $\omega_{0}$ を除いて完全に厳密解 と一 致 し, $s(x)$ の作用下においては境界層解に対応する項が 係数 $\omega_{0}$ を除いて厳密解と一致していることがわかる.
ゆえに, 近似合成解の誤差評価の基準は $\varepsilon_{t}$ と $\varepsilon, \varepsilon_{c}$ と $c$ なる弾性定数汇関連した係数にある.

\section{8. 異方性弾性厳密解}

Everstine \& Pipkin ${ }^{3)}$ の導入した一般化重調和方程 式をわれれれの議論における近似理論 [I] および [II] と対応させ Fourier 変換手法により解析する.

基礎方程式 (一般化重調和方程式):

$$
A \phi_{, y y y y}+B \phi_{, x x y y}+C \phi, x x x x=0
$$

$x$ 方向成分に対する特性方程式:

$$
A \lambda^{2}+B \lambda+C=0
$$

の大小の根をそれぞれ $1 / \varepsilon_{t}, \varepsilon_{c}$ とすると基礎方程式は 次のように書ける.

$$
\left(\varepsilon_{t}{ }^{2} \frac{\partial^{2}}{\partial y^{2}}+\frac{\partial^{2}}{\partial x^{2}}\right)\left(\frac{1}{\varepsilon_{c}^{2}} \cdot \frac{\partial^{2}}{\partial y^{2}}+\frac{\partial^{2}}{\partial x^{2}}\right) \phi(x, y)=0
$$

近似理論との対応を示すため上の特性根と関係する次の 変数を導入する.

$$
\bar{y}_{1}=\varepsilon_{c} y, \quad \bar{\eta}=y / \varepsilon_{t} .
$$

このとき, 上述の基礎方程式は次のようになる。

$$
\left(\frac{\partial^{2}}{\partial \bar{y}_{1}{ }^{2}}+\frac{\partial^{2}}{\partial x^{2}}\right)\left(\frac{\partial^{2}}{\partial \bar{\eta}^{2}}+\frac{\partial^{2}}{\partial x^{2}}\right) \phi=0 \cdots \cdots \cdots(36)^{\prime}
$$

近似理論の場合と同様に次のように議論を進める.

応力関数の変換 :

$$
\hat{\phi}(\xi, y)=\int_{-\infty}^{\infty} e^{-i \xi x} \phi(x, y) d x
$$

基礎方程式の変換 :

$$
\left(\frac{d^{2}}{d y^{4}}-\xi^{2} \cdot \frac{B}{A} \frac{d^{2}}{d y^{2}}+\xi^{4} \cdot \frac{C}{A}\right) \hat{\phi}(\xi, y)=0
$$

$y \rightarrow \infty$ で応力 free の境界条件より応力関数は次のよう に求められる.

$$
\begin{aligned}
& \hat{\phi}(\xi, y)=c_{1} \exp \left(-\frac{|\xi|}{\varepsilon_{t}} y\right)+c_{2} \exp \left(-|\xi| \varepsilon_{c} y\right) \\
& \phi(x, y)=\frac{1}{2 \pi} \int_{-\infty}^{\infty} e^{-i \xi x} \hat{\phi}(\xi, y) d \xi
\end{aligned}
$$

定数 $c_{1}, c_{2}$ は $y=0$ での境界条件により決定され, 応 力成分の Fourier 変換および逆変換はそれぞれ次のよ うに表わされる.

$$
\begin{aligned}
& \hat{\sigma}_{x x}(\xi, y)=\frac{d^{2}}{d y^{2}}(\hat{\phi}(\xi, y)), \\
& \hat{\sigma}_{y y}(\xi, y)=-\xi^{2} \hat{\phi}(\xi, y), \\
& \hat{\sigma}_{x y}(\xi, y)=-i \xi \frac{d}{d y}(\hat{\phi}(\xi, y)) . \\
& \sigma_{x x}(x, y)=\frac{1}{2 \pi} \int_{-\infty}^{\infty} e^{+i \xi x} \frac{d^{2} \hat{\phi}}{d y^{2}} d \xi, \\
& \sigma_{y y}(x, y)=-\frac{1}{2 \pi} \int_{-\infty}^{\infty} e^{+i \xi x \xi^{2} \hat{\phi} d \xi}, \\
& \sigma_{x y}(x, y)=-\frac{1}{2 \pi} \int_{-\infty}^{\infty} e^{+i \xi x} i \xi \frac{d}{d y} \hat{\phi} d \xi .
\end{aligned}
$$


以上で形式的準備は完了したので, 以下では近似理論に 対応する問題をこの節の厳密式によって解析する.

(A) $p(x)$ のみ作用する場合

境界条件は,

$$
\sigma_{y y}(x, 0)=p(x), \sigma_{x y}(x, 0)=0
$$

であり, (38), (39) を用いて定数 $c_{1}(\xi), c_{2}(\xi)$ は次の ように定まる.

$$
c_{1}(\xi)=\frac{\omega_{0}}{\xi^{2}} \varepsilon_{t} \varepsilon_{c} \hat{p}(\xi), c_{2}(\xi)=-\frac{\omega_{0}}{\xi^{2}} \hat{p}(\xi)
$$

ここに,

$$
\omega_{0}=\frac{1}{1-\varepsilon_{t} \varepsilon_{c}}
$$

したがって, 応力関数は（38）より次のように定まる.

$$
\begin{aligned}
& \hat{\phi}(\xi, y)=\frac{\omega_{0}}{\xi^{2}} \hat{p}(\xi)\left[\varepsilon_{t} \varepsilon_{c} e^{-|\xi| \eta}-e^{-|\xi| \bar{y}_{1}}\right] \\
& \phi(x, y)=F^{-1}[\hat{\boldsymbol{\phi}}(\xi, y) ; \xi \rightarrow x]
\end{aligned}
$$

応力成分は, (39) より次のように求まる.

$$
\begin{aligned}
& \sigma_{x x}(x, y)=\omega_{0}\left[-\varepsilon_{c}{ }^{2} G_{c}\left(x, \bar{y}_{1}\right) * p(x)\right. \\
& \left.+\frac{\varepsilon_{c}}{\varepsilon_{t}} G_{c}(x, \bar{\eta}) * p(x)\right], \\
& \sigma_{y y}(x, y)=\omega_{0}\left[G_{c}\left(x, \bar{y}_{1}\right) * p(x)\right. \\
& \left.-\varepsilon_{t} \varepsilon_{c} G_{c}(x, \bar{\eta}) * p(x)\right], \\
& \sigma_{x y}(x, y)=\omega_{0}\left[\varepsilon_{c} G_{s}\left(x, \bar{y}_{1}\right) * p(x)\right. \\
& \left.-\varepsilon_{c} G_{c}(x, \bar{\eta}) * p(x)\right] \text {. }
\end{aligned}
$$

ここに, $G_{c}(x),, G_{s}(x$,$) は (21) で定義されてい$ る. またこのとき, 応力関数は次のように表示できる.

$$
\begin{aligned}
\phi(x, y)=\omega_{0}[- & G_{c}\left(x, \bar{y}_{1}\right) * p(x) \\
& \left.+\varepsilon_{t} \varepsilon_{c} G_{c}(x, \bar{\eta}) * p(x)\right],
\end{aligned}
$$

(B) $s(x)$ のみ作用する場合

境界条件は,

$$
\sigma_{y y}(x, 0)=0, \sigma_{x y}(x, 0)=s(x)
$$

であり, (37), (38) より定数 $c_{1}(\xi), c_{2}(\xi)$ は次のよう に定まる。

$$
c_{1}(\xi)=\frac{i \omega_{0} \varepsilon_{t}}{\xi|\xi|} \hat{s}(\xi), c_{2}(\xi)=-c_{1}(\xi)
$$

これより応力関数および応力成分は次のように求まる.

$$
\begin{aligned}
& \hat{\phi}(\xi, y)=\frac{i \omega_{0} \varepsilon_{t}}{\xi|\xi|} \hat{s}(\xi)\left(-e^{-|\xi| \bar{y}_{1}}+e^{-\mid \xi i \bar{\eta}}\right) \\
& \phi(x, y)=F^{-1}[\hat{\phi}(\xi, y) ; \xi \rightarrow x] \\
& \sigma_{x x}(x, y)=\omega_{0}\left[-\varepsilon_{t} \varepsilon_{c}^{2} G_{s}\left(x, \bar{y}_{1}\right) * s(x)\right. \\
&\left.+\frac{1}{\varepsilon_{t}} G_{s}(x, \bar{\eta}) * s(x)\right], \\
& \sigma_{y y}(x, y)=\omega_{0}\left[\varepsilon_{t} G_{s}\left(x, \bar{y}_{1}\right) * s(x)\right. \\
&\left.-\varepsilon_{t} G_{s}(x, \bar{\eta}) * s(x)\right], \\
& \sigma_{x y}(x, y)= \omega_{0}\left[-\varepsilon_{t} \varepsilon_{c} G_{c}\left(x, \bar{y}_{1}\right) * s(x)\right. \\
&\left.+G_{c}(x, \bar{\eta}) * s(x)\right] .
\end{aligned}
$$

このとき, 応力関数は次のように表示できる.

$$
\begin{aligned}
\phi(x, y)= & \omega_{0}\left[-\varepsilon_{t} G_{s}\left(x, \bar{y}_{1}\right) * s(x)\right. \\
& \left.+\varepsilon_{t} G_{s}(x, \bar{\eta}) * s(x)\right]
\end{aligned}
$$

\section{9. 近似合成解と異方性厳密解の比較}

ここに近似合成解と異方性峳密解は（A）および（B) の場合，それぞれ次のようにまとめられる.

\section{(A) $p(x)$ が作用する場合}

近似合成解 : (34), 異方性厳密解 : (42)

(B) $s(x)$ が作用する場合

近似合成解 : (35), 異方性厳密解 : (43)

近似合成解と異方性㛜密解を比較して, 厳密解における 特性根 $\varepsilon_{t}$ および $\varepsilon_{c}$ をそれぞれ近似解における $\varepsilon$ およ び $c$ に置き換えて考えると両者の形式的相違は厳密解 における係数 (41), すなわち

$$
\begin{aligned}
\omega_{0}= & \frac{1}{1-\varepsilon_{t} \varepsilon_{c}}=\sum_{n=0}^{\infty}\left(\varepsilon_{t} \varepsilon_{c}\right)^{n} \\
& =1+\left(\varepsilon_{t} \varepsilon_{c}\right)+\left(\varepsilon_{t} \varepsilon_{c}\right)^{2}+\cdots \cdots
\end{aligned}
$$

であることがわかる. しかし，これは近似理論の出発点 となった高異方性物質に対しては， $\varepsilon_{t} \ll 1, \varepsilon_{c}<1$ であ り, 近似として $\omega_{0}=1$ とすることの誤差は $O\left(\varepsilon_{t} \varepsilon_{c}\right)$ の程 度であり無視し得るものである. ゆえに, 両者における 本質的比較は $\varepsilon_{t}$ と $\varepsilon, \varepsilon_{c}$ と $c$ をどの程度同一視し得る かといらことに帰着するが，(1) に示した一般化構成関 係と一般化重調和方程式の係数の関係を用いると, 高異 方性物質に対しては $O\left(\varepsilon_{t}\right)=O(\varepsilon), O\left(\varepsilon_{c}\right)=O(c)$ であ ることがわかる。

なお, $s(x)$ の作用下において, 近似合成解に非伸張 仮定解が出現しないのは近似解の本質的性格によるもの であり，逆に境界層の意味がはっきりとうかがえるであ ろら.

\section{0．基本的荷重による検討}

先に示したように半無限体の表面に $p(x), s(x)$ のお のおのが作用する場合, 㛜密解および近似解一般式がそ れぞれ (42),(34) および (43),(35) により基礎関数と の合成積として得られたが，ここでは簡単な基本的荷重 が作用する場合について応力の陽な表示を示すと同時 に，その幾つかにつき厳密解と近似解の相違ならびに特 性を示す（ここでは, fiber に垂直な荷重 $p(x)$ が作用 する場合のみ示すが, $s(x)$ が作用した場合も同じ手法 で求められる.ここでの目的は, 厳密解と近似解の基本 的性質を具体的に示すことであるので, $p(x)$ のみに対 する議論で十分であり, $s(x)$ 作用の場合の具体例は省 略する). なお,ここに示す荷重に対しては合成積は簡 単に積分できるので結果のみ示す. 


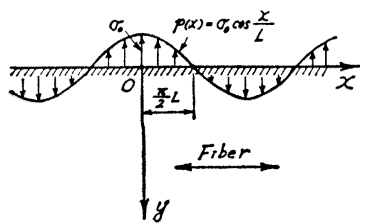

Fig. 3 Half Plane Subjected to Sinusoidal Normal Stress $p(x)=\sigma_{0} \cos \frac{x}{L}$ at the Boundary.

a) fiber に垂直な荷 重 $p(x)$ のみが作用する 場合

(1) cosine 分布荷重 (Fig. 3 参照)

境界層の厚さと減衰長 の概念を明確にするた め，まず特性長を $L$ と するような分布荷重を考

える.境界条件は，

$$
\left.\begin{array}{l}
\sigma_{y y}(x, 0)=p(x)=\sigma_{0} \cos \frac{x}{L}, \\
\sigma_{x y}(x, 0)=s(x)=0 .
\end{array}\right\}
$$

で与えられ, 厳密解は一般解 (42) において $p(x)=$ $\sigma_{0} \cos \frac{x}{L}$ としてやればよく, その結果次のようになる.

$$
\begin{aligned}
\sigma_{x x}= & \omega_{0}\left\{-\varepsilon_{c}^{2} \exp \left(-\frac{\varepsilon_{c}}{L} y\right)\right. \\
& \left.+\frac{\varepsilon_{c}}{\varepsilon_{t}} \exp \left(-\frac{1}{L \varepsilon_{t}} y\right)\right\} \sigma_{0} \cos \frac{x}{L}, \\
\sigma_{y y}= & \omega_{0}\left\{\exp \left(-\frac{\varepsilon_{c}}{L} y\right)\right. \\
& \left.-\varepsilon_{t} \varepsilon_{c} \exp \left(-\frac{1}{L \varepsilon_{t}} y\right)\right\} \sigma_{0} \cos \frac{x}{L}, \\
\sigma_{x y}= & \omega_{0}\left\{\varepsilon_{c} \exp \left(-\frac{\varepsilon_{c}}{L} y\right)\right. \\
& \left.-\varepsilon_{c} \exp \left(-\frac{1}{L \varepsilon_{t}} y\right)\right\} \sigma_{0} \sin \frac{x}{L},
\end{aligned}
$$

他方, 近似解の方は一般解 (34) において $p(x)=$ $\sigma_{0} \cos \frac{x}{L}$ とおくことにより, 上記の応力式 (45) の係 数を $\omega_{0} \rightarrow 1.0, \varepsilon_{t} \rightarrow \varepsilon, \varepsilon_{c} \rightarrow c$ とおいてやったものに一 致するので式の再録は省略する.

ここで, Pipkin \& Rogers ${ }^{2}$ が行ったように, $\sigma_{y y}$ が 境界荷重の $e^{-1}$ 倍に減衰するときの $y$ の值を減衰長と し, また $\sigma_{x x}$ が境界荷重の $e^{-1}$ 倍に減衰するときの $y$ の值を境界層厚として定義するものとすれば, 減衰長は $0(L / c)$, および境界層厚は $0(L \varepsilon)$ となり, 非伸張仮定 解に対応する各式の右辺第一項は長距離にまで伝播する 特徵を持つことがわかる. また, 境界層仮定解に対応す る上式の右辺第二項は，境界近傍においてのみ強い影響 を与えることがわかる.

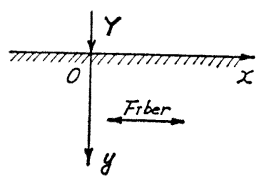

Fig. 4 Half Plane Subjected to a Normal Concentrated Force $Y$ at the Boundary.
(2) 点集中荷重 (Fig.

\section{4 参照)}

作用荷重 $p(x)$ を $p$ $(x)=-Y \delta(x)$ とおいて やればよく, 厳密解およ び近似解はそれぞれ次の ようになる。

綮密解 ${ }^{12)}$ :

$$
\begin{aligned}
& \sigma_{x x}=\frac{\omega_{0}}{\pi} Y\left[\varepsilon_{c}{ }^{2} \frac{\bar{y}_{1}}{x^{2}+\bar{y}_{1}{ }^{2}}-\frac{\varepsilon_{c}}{\varepsilon_{t}} \cdot \frac{\bar{\eta}}{x^{2}+\bar{\eta}^{2}}\right], \\
& \sigma_{y y}=\frac{\omega_{0}}{\pi} Y\left[-\frac{\bar{y}_{1}}{x^{2}+\bar{y}_{1}{ }^{2}}+\varepsilon_{t} \varepsilon_{c} \frac{\bar{\eta}}{x^{2}+\bar{\eta}^{2}}\right], \\
& \sigma_{x y}=\frac{\omega_{0}}{\pi} Y\left[-\varepsilon_{c} \frac{x}{x^{2}+\bar{y}_{1}{ }^{2}}+\varepsilon_{c} \frac{x}{x^{2}+\bar{\eta}^{2}}\right] .
\end{aligned}
$$

近似解 :

これは上式で

$\omega_{0} \rightarrow 1.0$,

$\varepsilon_{t} \rightarrow \varepsilon, \varepsilon_{c} \rightarrow c$,

$\bar{y}_{1} \rightarrow y_{1}, \bar{\eta} \rightarrow \eta$

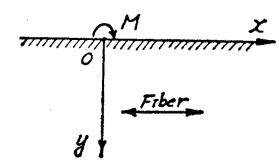

Fig. 5 Half Plane Subjected to a Concentrated Couple $M$ at the Boundary.

と置きなおしてやったも のと一致する.

（3) 集中モーメント荷重 (Fig. 5 参照)

厳密解 :

$$
\left.\begin{array}{l}
\sigma_{x x}=\frac{\omega_{0}}{\pi} M\left[\varepsilon_{c}^{2} \frac{x \bar{y}_{1}}{\left(x^{2}+\bar{y}_{1}^{2}\right)^{2}}-\frac{\varepsilon_{c}}{\varepsilon_{t}} \frac{x \bar{\eta}}{\left(x^{2}+\bar{\eta}^{2}\right)^{2}}\right], \\
\sigma_{y y}=\frac{\omega_{0}}{\pi} M\left[-\frac{x \bar{y}_{1}}{\left(x^{2}+\bar{y}_{1}^{2}\right)^{2}}+\varepsilon_{t} \varepsilon_{c} \frac{x \vec{\eta}}{\left(x^{2}+\bar{\eta}^{2}\right)^{2}}\right], \\
\sigma_{x y}=\frac{\omega_{0}}{\pi} M\left[-\varepsilon_{c} \frac{x^{2}-\bar{y}_{1}^{2}}{\left(x^{2}+\bar{y}_{1}^{2}\right)^{2}}+\varepsilon_{c} \frac{x^{2}-\bar{\eta}^{2}}{\left(x^{2}+\bar{\eta}^{2}\right)^{2}}\right] .
\end{array}\right\}
$$

\section{近似解 :}

この場合も上式で（47）のような係数を代入してやれ ば求まる. 点集中荷重および集中モーメント荷重の解を 通じ, また㛜密解および近似解を通じ高異方性極限 $\left(\varepsilon_{t}\right.$ $\left.\rightarrow 0, \varepsilon_{c} \rightarrow 0\right)$ においては, $\sigma_{x x}=O\left(1 / \varepsilon_{t}{ }^{2}\right)$ が支配的であ り, fiber に垂值な荷重が作用しても境界のごく近傍に, fiber 方向の直応力 $\sigma_{x x}$ が強く応答することを示してい る.

(4) 内部点集中荷重 (Fig. 6 参照)

図に示すように State I の応力状態は, State II と State III の重ね合わせで得られる.

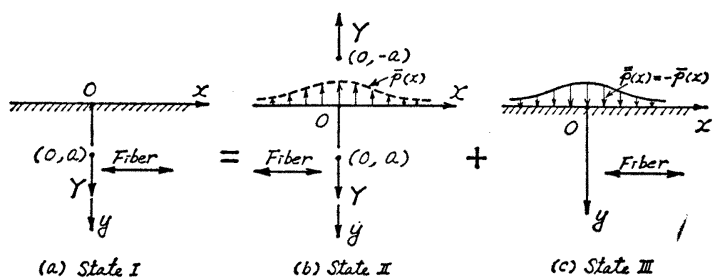

Fig. 6 Half Plane Subjected to a Vertical Concentrated Force $Y$ at the Finite Depth $y=a$.

厳密解 ${ }^{12)}$ :

点集中荷重解の重ね合わせにより State II の応力は 次式で求められる.

$$
\begin{aligned}
\bar{\sigma}_{x x}= & \frac{\omega_{0}}{\pi} Y\left\{\varepsilon_{c}^{2} G_{c}\left[x, \varepsilon_{c}(y-a)\right]\right. \\
& -\varepsilon_{c}^{2} G_{c}\left[x, \varepsilon_{c}(y+a)\right]-\frac{\varepsilon_{c}}{\varepsilon_{t}} \cdot G_{c}\left[x, \frac{y+a}{\varepsilon_{t}}\right]
\end{aligned}
$$




$$
\begin{aligned}
& \left.+\frac{\varepsilon_{c}}{\varepsilon_{t}} \cdot G_{c}\left[x, \frac{y+a}{\varepsilon_{t}}\right]\right\}, \\
\bar{\sigma}_{y y}= & \frac{\omega_{0}}{\pi} Y\left\{-G_{c}\left[x, \varepsilon_{c}(y-a)\right]\right. \\
& +G_{c}\left[x, \varepsilon_{c}(y+a)\right]+\varepsilon_{t} \varepsilon_{c} G_{c}\left[x, \frac{y-a}{\varepsilon_{t}}\right] \\
& \left.-\varepsilon_{t} \varepsilon_{c} G_{c}\left[x, \frac{x+a}{\varepsilon_{t}}\right]\right\}, \\
\bar{\sigma}_{x y}= & \frac{\omega_{0}}{\pi} Y\left\{-\varepsilon_{c} G_{s}\left[x, \varepsilon_{c}(y-a)\right]\right. \\
& +\varepsilon_{c} G_{s}\left[x, \varepsilon_{c}(y+a)\right]+\varepsilon_{c} G_{s}\left[x, \frac{y-a}{\varepsilon_{t}}\right] \\
& \left.-\varepsilon_{c} G_{s}\left[x, \frac{y+a}{\varepsilon_{t}}\right]\right\} .
\end{aligned}
$$

境界 $y=0$ での応力は

$$
\begin{aligned}
& \lim _{y \rightarrow 0} \bar{\sigma}_{y y}(x, y) \equiv \bar{p}(x) \\
& \quad=2 \omega_{0} Y\left[G_{c}\left(x, \varepsilon_{c} a\right)-\varepsilon_{t} \varepsilon_{c} G_{c}\left(x, \frac{a}{\varepsilon_{t}}\right)\right] \\
& \lim _{y \rightarrow 0} \bar{\sigma}_{x y}(x, y)=0
\end{aligned}
$$

State III に対する境界条件は次式で与えられる.

$\lim \bar{\sigma}_{y y}(x, y) \equiv \bar{p}(x)=-\bar{p}(x)$

一般解 (42) に $\overline{\bar{p}}(x)$ を代入し, 基礎関数の 合成積の 簡単な関係式

$$
\begin{aligned}
& G_{c}\left(x, \bar{y}_{1}\right) * G_{c}\left(x, \varepsilon_{c} a\right)=\frac{1}{\pi} \frac{\bar{y}_{1}+\varepsilon_{c} a}{x^{2}+\left(\bar{y}_{1}+\varepsilon_{c} a\right)^{2}} \\
& G_{s}\left(x, \bar{y}_{1}\right) * G_{c}\left(x, \varepsilon_{c} a\right)=\frac{1}{\pi} \frac{x}{x^{2}+\left(\bar{y}_{1}+a / \varepsilon_{t}\right)^{2}}
\end{aligned}
$$

に注意すると, State III の応力は次のようになる.

$$
\begin{aligned}
\bar{\sigma}_{x x}= & \frac{2 \omega_{0}{ }^{2}}{\pi} Y\left\{\varepsilon_{c}{ }^{2} G_{c}\left[x, \bar{y}_{1}+\varepsilon_{c} a\right]\right. \\
& -\varepsilon_{t} \varepsilon_{c}{ }^{3} G_{c}\left[x, \bar{y}_{1}+\frac{a}{\varepsilon_{t}}\right]-\frac{\varepsilon_{c}}{\varepsilon_{t}} \cdot G_{c}\left[x, \bar{\eta}+\varepsilon_{c} a\right] \\
& \left.+\varepsilon_{c}{ }^{2} G_{c}\left[x, \bar{\eta}+\frac{a}{\varepsilon_{t}}\right]\right\}, \\
\overline{\bar{\sigma}}_{y y}= & \frac{2 \omega_{0}{ }^{2}}{\pi} Y\left\{-G_{c}\left[x, \bar{y}_{1}+\varepsilon_{c} a\right]\right. \\
& +\varepsilon_{t} \varepsilon_{c} G_{c}\left[x, \bar{y}_{1}+\frac{a}{\varepsilon_{t}}\right]+\varepsilon_{t} \varepsilon_{c} G_{c}\left[x, \bar{\eta}+\varepsilon_{c} a\right] \\
& \left.-\left(\varepsilon_{t} \varepsilon_{c}\right)^{2} G_{c}\left[x, \bar{\eta}+\frac{a}{\varepsilon_{t}}\right]\right\}, \\
& 2 \omega_{0}^{2} Y\left\{-\varepsilon_{c} G_{s}\left[x, \bar{y}_{1}+\varepsilon_{c} a\right]\right. \\
\pi & \bar{\sigma}_{x y} \\
& +\varepsilon_{t} \varepsilon_{c}{ }^{2} G_{s}\left[x, \bar{y}_{1}+\frac{a}{\varepsilon_{t}}\right]+\varepsilon_{c} G_{s}\left[x, \bar{\eta}+\varepsilon_{c} a\right] \\
& \left.-\varepsilon_{t} \varepsilon_{c}{ }^{2} G_{s}\left[x, \bar{\eta}+\frac{a}{\varepsilon_{t}}\right]\right\} .
\end{aligned}
$$

これより，

$$
\begin{aligned}
& \lim _{y \rightarrow 0} \sigma_{y y}(x, y)=\lim _{y \rightarrow 0}\left[\bar{\sigma}_{y y}(x, y)+\overline{\bar{\sigma}}_{y y}(x, y)\right]=0, \\
& \lim _{y \rightarrow 0} \sigma_{x y}(x, y)=\lim _{y \rightarrow 0}\left[\bar{\sigma}_{x y}(x, y)+\bar{\sigma}_{x y}(x, y)\right]=0 .
\end{aligned}
$$

となり，自由境界の条件は満足されている．ゆえに， State I の応力状態の厳密解は (49) と (50) の応力成 分をそれぞれ重ね合わせた次式で表わされる。

$$
\left.\begin{array}{l}
\sigma_{x x}=\bar{\sigma}_{x x}+\overline{\bar{\sigma}}_{x x} \\
\sigma_{y y}=\bar{\sigma}_{y y}+\overline{\bar{\sigma}}_{y y} \\
\sigma_{x y}=\bar{\sigma}_{x y}+\overline{\bar{\sigma}}_{x y}
\end{array}\right\}
$$

\section{近似解:}

集中荷重解の 重㸚わせにより, State II の応力は (49)の係数を（47）のように置きかえてやったものに 等しくなる. 境界 $(y=0)$ 上の応力は

$$
\begin{aligned}
\lim _{y \rightarrow 0} \bar{\sigma}_{y y}(x, y) & =\bar{p}_{1}(x) \\
& =2 Y\left[G_{c}(x, c a)-\varepsilon c G_{c}(x, a / \varepsilon)\right], \\
\lim _{y \rightarrow 0} \bar{\sigma}_{x y}(x, y) & =0 .
\end{aligned}
$$

となる。

State III に対する境界条件は次式で表わされる.

$$
\lim _{y \rightarrow 0} \overline{\bar{\sigma}}_{y y}(x, y) \equiv \overline{\bar{p}}_{1}(x)=-\bar{p}_{1}(x)
$$

近似一般解 (34) に $\bar{p}_{1}(x)$ を代入することにより, 览 密解の場合と同様にして State III に対寸る応力 $\left\{\bar{\sigma}_{x x}\right.$, $\left.\overline{\bar{\sigma}}_{y y}, \overline{\bar{\sigma}}_{x y}\right\}$ が得られ，これとの重社合わせとして State I に対する近似解（第一次補正解）の応力は, 異方性 厳密解である (49), (50) および (51) においてそれら の式中に現われる係数を（47）のように置き換えてやっ たもので与えられることになる.ただし，こらして得ら れた式のらち $y \rightarrow 0$ のときの $\sigma_{y y} お よ ひ ゙ \sigma_{x y}$ は次式:

$$
\begin{aligned}
& \lim _{y \rightarrow 0} \sigma_{y y}(x, y)= \\
& -\varepsilon c \frac{2 Y}{\pi}\left[-\frac{c a}{x^{2}+(c a)^{2}}+\varepsilon c \frac{a / \varepsilon}{x^{2}+(a / \varepsilon)^{2}}\right] \\
& \lim _{y \rightarrow 0} \sigma_{x y}(x, y)=0
\end{aligned}
$$

となって, 境界上で $\sigma_{y y}=0$ なる条件がこの過程で実現 できない，この理由は，厳密解である一般式 (42) にお ける係数 $\omega_{0}$ が近似解の一般式 (34) においては出現せ ず, 単位の值となるためである. しかるに, 厳密解のパ ラメーター $\left\{\varepsilon_{t}, \varepsilon_{c}\right\}$ と近似解のパラメーター $\{\varepsilon, c\}$ は 高異方性極限においては同じオーダー $\left(\varepsilon_{t} \fallingdotseq \varepsilon, \varepsilon_{c} \fallingdotseq c\right)$ で あり，物理的には類似した意味を持ち応力の值そのもの にはほとんど影響を与えないにもかかわらず,この一般 化重調和方程式の特性根 $\varepsilon_{t}$ および $\varepsilon_{c}$ にからむ係数 $\omega_{0}$ は, 高異方性極限において厳密解と近似解を特徵ゔける 重要な意味を持っていると指摘できよう.

なお，ここで出現した境界応力 $\sigma_{y y}$ を $\bar{p}_{2}(x)=-$ $\lim _{y \rightarrow 0} \sigma_{y y}(x, y)$ とおいて, 近似一般解 (34) に代入する ことにより,さらに自由境界の条件に近ゔけることは可 能であるが，ここでの目的は両者の解の特質を探ること であるから, 近似解の第一近似を示すことにとどめる. なお，この第一近似において出現した境界応力 $\sigma_{y y}$ の オーダーは, $\sigma_{y y}(x, 0)=0\left(\varepsilon c^{2}\right)$ であり, 近似基礎式が 
正当であるような高異方性の場 $\varepsilon \ll c<1$ に対しては， 十分な精度で自由境界の条件を満足していることがわか る.

\section{1. 結言}

材料の理想化に対する解析手法に対するこの一連の流 れについていくつかの指摘ができる. 理想化とは,「ょ り特徵的に」その材料特性を提示しようとするものであ り，「非圧縮非伸張仮定理論」に示されたように singu・ lar fiber と normal-line なる二つの応力特異 fiber の 出現, 近似理論 [I] における fiber の出現, そしてこ れらの fiber に沿い減衰なく無限距離にまで不定応力 （物理的には作用外力そのもの）が伝達されること. 現 実の高異方性と見なし得る物質においては，この傾向の 可能性が十分考え得ること．これらのことは，古典異方 性弾性論の基礎式では明確には表示し得ない高異方性体 の持つ本質的性格を示しており, 古典理論との相違点で もある. Pipkin らも指摘しているように，ここで次の ような疑問が提示できる.『古典的かつ危険な言い方を すれば, 合力, 合モーメントの等価性は外力作用点近傍 を除けば系全体の応力の等価性を保証する, とする St. Venant 原理はここでどう 解釈すべきか？』，また㣀 の応力状態とは? 厳密式なるものが, はたしてこの異 方性場を正当に表示し得るか？』少なくとも,ここで 対象とした紪維複合材料のような現実の高異方性物質に 対しては, この原理使用に際して十分なる注意を要する ことがここで得られたことからうかがえる．言葉をかえ るならば, 数学的極限を物理的極限と解釈して実在物質 に適用することの危険性を示しているとも言えよう. Hoff の例 ${ }^{13)}$ に見られるように立体トラスや補強薄肉円 筒に対しこの原理が成立しない例は，弱体物質に超剛性 が埋め込まれた物質という形で，ある意味では本論文に 言う物質定数の極限として捉えることにより説明がつ く. Sternberg ${ }^{14)}$ がいらような空間的尺度だけからでは この原理は把握しきれるものではなく,さらに広い意味 をつける必要があると思われる. また，異方性弾性論の 出発点はあくまで等方性物質からの拡張を基礎としてお り，FRCM などの現在多数出現しつつある新物質に対 しても正当に適用できるか否かは十分なチェックが必要 である.なお,ここでの理想化の流れは非圧縮, 非伸張 といら内部拘束をもつ物質の解析を出発点としており， 完全剛から現実への接近を計ったものであり，古典異方 性弹性論とは両極端としての出発点を持つと考えられ， 材料特性の把握と再考察への足掛かりとなりうるものと 考えられる.

なお，本論文においても示されているように $[\varepsilon \rightarrow 0$ $\left.\left(\varepsilon_{t} \rightarrow 0\right), c \rightarrow 0\left(\varepsilon_{c} \rightarrow 0\right)\right]$ なる二つの材料定数比の極 限においては両者は一致しており,この古典異方性理論 とここでの近似理論は全く相矛盾したものではないこと を再度強調しておきたい，一つの指摘として古典的な意 味における St. Venant 原理が正当ではなくなる異方 性比の限界が存在するということである. 一般にこの原 理は, 空間的応力伝達機構について述べたものであり, ここでの主張はそれに材質的考察をも含めてより正確な 記述が必要であることを主張するものである. また, 異 方性の複雑な弾性定数間の関係を一般化重調和方程式の 二つの特性根で陽に表示し, それを重調和方程式として 提示しようとするこの考えは FRCM に限らず一般的に も有利な表記であると思われ，これから広く活用される べきものであり, 厳密式の簡単化ならびに解析手法の簡 単化の両者, 相伴なったものとして, 異方性㛜密解の追 求とともに研究されるべき課題と思われる.

\section{参考文 献}

1）たとえば Eringen, A.C. and E.S. Suhubi : Nonlinear Theory of Simple Microelastic Solids, Int. J. Eng. Sci., Vol. 2 (1964), pp. 189 203, pp. 389 404, Ariman, T., M.A. Turk and N.D. Sylvester : Microcontinuum Fluid Mechanics-A Review, Int. J. Eng. Sci., Vol. 11 (1973), pp. 905 930.

2) Pipkin, A.C. and T.G. Rogers : Plane Deformations of Incompressive Fiber-Reinforced Materials, J. Appl. Mech., Vol. 38 (1971), pp. 634 640.

3) Everstine, G.C. and A.C. Pipkin : Stress Channeling in Transversely Isotropic Elastic Composites, ZAMP Vol. 22 (1971), pp. 825 834.

4) England, A.H., J.E. Ferrier and J.N. Thomas : Plane Strain and Generalized Plane Stress Problems for Fibre-Reinforced Materials, J. Mech. Phys. Solids, Vol. 21 (1973), pp. 279 301.

5) Everstine, G.C. and A.C. Pipkin : Boundary Layers in Fiber-Reinforced Materials, J. Appl. Mech., Vol. 40 (1973), pp. 518 522.

6) Spencer, A.J.M. : Boundary Layers in Highly Anisotropic Plane Elasticity, Int. J. Solids Structures, Vol. 25 (1974), pp.1103 1123.

7) Biot, M.A. : Fundamental Skin Effect in Anisotropic Solid Mechanics, Int. J. Solids Structures, Vol. 17 (1966), pp. 645 663.

8) Pipes, R.B. and N.J. Pagarno: Interlaminar Stress in Composite Laminates-An Approximate Elasticity Solution, J. Appl. Mech., Vol. 41 (1974), pp. 668 672.

9) Lekhnitskii, S.G. : Anisotropic Plates, (Eng. Trans), Gordon and Breach (1968).

10) Markham, M.F. : Measurement of the Elastic Constants of Fibre Composites by Ultrasonics, Composites, Vol. 1 (1970), p. 145.

11) Sneddon, I.N. : Fourier Transforms, McGraw-Hill (1950).

12) Conway, H.D. : Some Problems of Orthotropic Plane Stress, J. Appl. Mech., Vol. 25 (1953), pp. 72 76; Conway, H.D. The Stress Distributions Induced by Concentrated Loads Acting in Isotropic and Ortho- 
tropic Half Planes, J. Appl. Mech., Vol. 25 (1953), pp. $82 \sim 86$.

13) Hoff, N.J. : The Applicability of Saint-Venant's Principle to Airplane Structures, J. Aeron. Sci., Vol. 12 (1945), pp. 455 460; Fung, Y.C., Foundations of Solid Mechanics, Prentice-Hall (1965), pp. 306 309, 大橋義夫ほか訳: 固体の力学/理論, 培風館, pp. $313 \sim 316$.
14) Sternberg, E. : On Saint-Venant's Principle, Quat. Appl. Math., Vol. 11 (1954), pp. 394 402.

15）たとえば, Noll, W.: A Mathematical Theory of the Mechanical Behavior of Continuous Media, Rat. Mech. Anal., Vol. 2 (1958), pp. 197 226; 徳岡辰雄: 有理力学一新しい連続体力学, 材料, 第 23 巻 (1974) 253 号～第 24 巻 (1975) 258 号.

(1976.12.6 - 受付) 